\title{
PHYTOPHILOUS CHIRONOMIDAE (DIPTERA) AND OTHER MACROINVERTEBRATES IN THE OX-BOW INFERNÃO LAKE (JATAÍ ECOLOGICAL STATION, LUIZ ANTÔNIO, SP, BRAZIL)
}

\author{
TRIVINHO-STRIXINO, S., ${ }^{1}$ CORREIA, L. C. S. ${ }^{2}$ and SONODA, K. \\ ${ }^{1}$ Depto. de Hidrobiologia, UFSCar, C.P. 676, CEP 13.565-905, São Carlos, SP, Brazil \\ ${ }^{2}$ PPG-ERN/UFSCar, C.P. 676, CEP 13.565-905, São Carlos, SP, Brazil \\ Correspondence to: Depto. de Hidrobiologia, UFSCar, São Carlos, C.P. 676, CEP 13.565-905, \\ São Carlos, SP, Brazil, e-mail: strixino@ power.ufscar.br \\ Received August 4, 1999 - Accepted December 13, 1999 - Distributed August 31, 2000
}

(With 4 figures)

\begin{abstract}
Infernão Lake, located within the Jataí Ecological Station in Luiz Antônio Municipal district (São Paulo State, Brazil), is one of the most typical ox-bow lake of the Mogi-Guaçu River, and it presents, as the main feature, its great quantity of aquatic macrophytes, whose intensive development, in the last years practically covered the whole mirror of water. With the purpose to point out the composition and to establish the relative participation of the phytophilic zoocoenosis that inhabits the different macrophytes of that lake, a collection program of the main vegetation stands was established. The collections, were carried out randomly, during dry season (1994), in stands of Salvinia auriculata, Utricularia sp., Cabomba piauhyensis, Eichhornia azurea and Scirpus cubensis being used specific methodology for each vegetable type. The analysis of the different macrophytes showed the presence of 4,130 macroinvertebrates of 28 families, in which Chironomidae (Diptera) and Naididae (Oligochaeta) were the most representative, contributing on the average with $51 \%$ and $25 \%$ of the total fauna. Asheum, Beardius, Chironomus, Goeldichironomus, Parachironomus and Polypedilum were the most abundant Chironomidae genera. Species of the genus Dero (Dero) and D. (Aulophorus) represented the most typical Naididae of the phytofauna. With clear faunistic gradient from the shore to the center of the lake, the taxocoenosis indicated low similarity (PSc $<50 \%$ ), evidencing its own characteristics of each biotope. On the contrary, there was a high similarity (PSc $>60 \%$ ) among the associated communities on different vegetables, when grouped into feeding guilds, with expressive participation, in most of the macrophytes, of the collector-gatherers category, except on S. auriculata, whose predators (> 50\%) and collector-filterers (> 20\%) dominance turned that zoocoenosis distinct from the others.
\end{abstract}

Key words: Chironomidae (Diptera), aquatic macroinvertebrates, aquatic phytofauna.

\section{RESUMO}

\section{Chironomidae (Diptera) Fitófilos e outros Macroinvertebrados da Lagoa do Infernão (Estação Ecológica de Jataí, Luiz Antônio, SP, Brasil)}

A Lagoa do Infernão, situada dentro da Estação Ecológica de Jataí no Município de Luiz Antônio (São Paulo), é uma das mais características lagoas marginais do Rio Mogi-Guaçu e apresenta, como principal característica grande quantidade de macrófitas aquáticas, cujo intenso desenvolvimento, nos últimos anos, acarretou o recobrimento de quase todo o espelho d'água. Com o objetivo de determinar a composição e estabelecer a participação relativa da zoocenose fitófila dessa lagoa, foi estabelecido um programa de coleta dos principais "stands" de vegetação. As coletas, realizadas no período de 
estiagem (1994), foram efetuadas ao acaso, em "stands" de Salvinia auriculata, Utricularia sp., Cabomba piauhyensis, Eichhornia azurea e Scirpus cubensis utilizando-se metodologia específica para cada tipo de vegetal. A análise das diferentes macrófitas indicou a presença de 4.130 macroinvertebrados de 28 famílias, das quais Chironomidae (Diptera) e Naididae (Oligochaeta) foram as mais representativas, contribuindo em média com $51 \%$ e $25 \%$ da fauna total. Asheum, Beardius, Chironomus, Goeldichironomus, Parachironomus e Polypedilum foram os gêneros mais abundantes entre os Chironomidae. Espécies do gênero Dero (Dero) e D. (Aulophorus) representaram os Naididae mais característicos da fitofauna. Com nítido gradiente faunístico das margens para o centro da lagoa, as taxocenoses indicaram baixa similaridade (PSc $<50 \%$ ), evidenciando características próprias de cada biótopo. Ao contrário, houve elevada similaridade (PSc > 60\%) entre as comunidades associadas aos diferentes vegetais quando agrupadas em guildas de alimentação, com significativa participação, na maioria das macrófitas, da categoria de coletores-roçadores, exceto em S. auriculata, cuja predominância de predadores $(>50 \%)$ e coletores-filtradores $(>20 \%)$ tornou essa zoocenose distinta das demais.

Palavras-chave: Chironomidae (Diptera), macroinvertebrados aquáticos, fitofauna aquática.

\section{INTRODUCTION}

In consequence of a geological fissure, and of the combined and constant erosion and sedimentation activity, the Mogi Guaçu River presents meandrous surface in its medium section, associated to numerous typical horseshoe lagoons (oxbow lakes), frequently disconnected of its main channel (Gandolfi, 1968) (Fig.1b). According to Esteves (1988), these lacustrine systems maybe the most common within the Brazilian territory. Among the 15 riverside lagoons located in the Jataí Ecological Station, in the Luiz Antônio Municipal district $\left(21^{0} 33^{\prime}-21^{0} 37^{\prime} \mathrm{S}\right.$ and $\left.47^{0} 45^{\prime}-47^{0} 51^{\prime} \mathrm{W}\right)$ (Fig. 1a), the Infernão Lake seems to be one of the oldest. It is an infiltration lake, which presents, as its main characteristic, many aquatic macrophytes (Fig. 1c). According to some authors, these macrophytes occupy, in the rain season, $65 \%$ of the total area of the lake (Nogueira, 1989; Coutinho, 1989). In the last years these macrophytes practically covered most of the mirror of water, mainly for the accelerated growth of Scirpus cubensis (Correia \& Trivinho-Strixino, 1998). Previous studies carried out in this lake indicated low contents of dissolved $\mathrm{O}_{2}$ in all water-column (Antônio, 1996), a virtual absence of a typical macrobenthic fauna (Strixino et al., 1997) and the presence of a rich phytophilous fauna (TrivinhoStrixino et al. 1998; Correia \& Trivinho-Strixino, 1998). With the objective of analyzing the faunistic composition and of comparing the structure of the phytophylic zoocoenosis that inhabits different macrophytes a study was done about this community associate in a vegetable gradient from the margin to the middle of the lake.

\section{SAMPLING AND ANALYSIS}

The macrophytes were collected following a profile and general features of macrophyte stands zonation, from the margins to the center of the lake (Fig. 2a). They were elected the predominant Scirpus cubensis, Eichhornia azurea, Cabomba piauhyensis, Utricularia sp. and Salvinia auriculata. Other macrophytes are found in the lake, even so with more scattered occurrence (Eleocharis sp., Ceratophyllum demersum, Panicum pernambucensis and Ludwigia sp.).

The collections were carried out during dry season (May/94 - July/94), being used differentiated methodology for each vegetable. Thus, for the emergent and rooted macrophytes (S. cubensis and $E$. azurea), they were removed after the separation of the buoyant parts; submerged macrophytes $(C$. piauhyensis and Utricularia sp.) were collected whole, in the same way that $S$. auriculata. With the purpose of making more uniform analysis, in the numeric estimates, were considered together the plant volume and the volume of the surrounding water. For each vegetable, 3 units of sampling were removed defined this way: $S$. auriculata - volume of each sample $=0.004 \mathrm{~m}^{3} ;$ Utricularia sp. and $C$. piauhyensis - volume of each sample $=0.002 \mathrm{~m}^{3}$; E. azurea - volume of each sample $=0.004 \mathrm{~m}^{3}$ and S. cubensis - volume of each sample $=0.006 \mathrm{~m}^{3}$. The results were expressed in mean number of individuals per $0.01 \mathrm{~m}^{3}$ (n. $0.01 \mathrm{~m}^{-3}$ ) (including plant 
+ water). Furthermore, the communities were analyzed according to community indexes such as faunistic taxa richness $\left(\mathrm{n}^{\circ}\right.$ of taxonomic operational units - OTUs), Margalef's index of richness $\left(\mathrm{I}_{\mathrm{MG}}\right)$ and Shannon's index of diversity ( $\left.\mathrm{H}^{\prime}\right)$. Coenotic affinity was analyzed through the Similarity Percentage (PSc) (Whittaker \& Fairbanks, 1958). The functional feeding group classification followed Merritt \& Cummins (1995).

\section{RESULTS AND DISCUSSION}

\section{Faunistic composition}

In the different macrophyte stands were separated 4,130 individuals from 28 macroinvertebrate families (twenty-five of the which Insecta). In spite of the great variety of families, the majority had little contribution, almost always presenting low participation $(<1 \%)$. Chironomidae (Diptera) and Naididae (Oligochaeta) had more significant participation in most of the macrophytes, contributing together with $76 \%$ of the total phytofauna. Nymphs of Odonata (Coenagrionidae and Libellulidae) and larvae of Culicidae (Diptera) had expressive participation in the faunistic structure of $S$. auriculata, contributing with approximately $40 \%$ of its phytofauna. The submerged macrophytes (C. piauhyensis and Utricularia sp.) sheltered the largest numeric density of individuals, respectively $1,079.8$ and 746.9 individuals. $0.01 \mathrm{~m}^{-3}$, followed by the emergent ones ( $S$. cubensis and E. azurea) with 565.4 and 570.4 individuals. $0.01 \mathrm{~m}^{-3} ; S$. auriculata presented the smallest average numeric density with 354.8 individuals. $0.01 \mathrm{~m}^{-3}$ (Table 1).

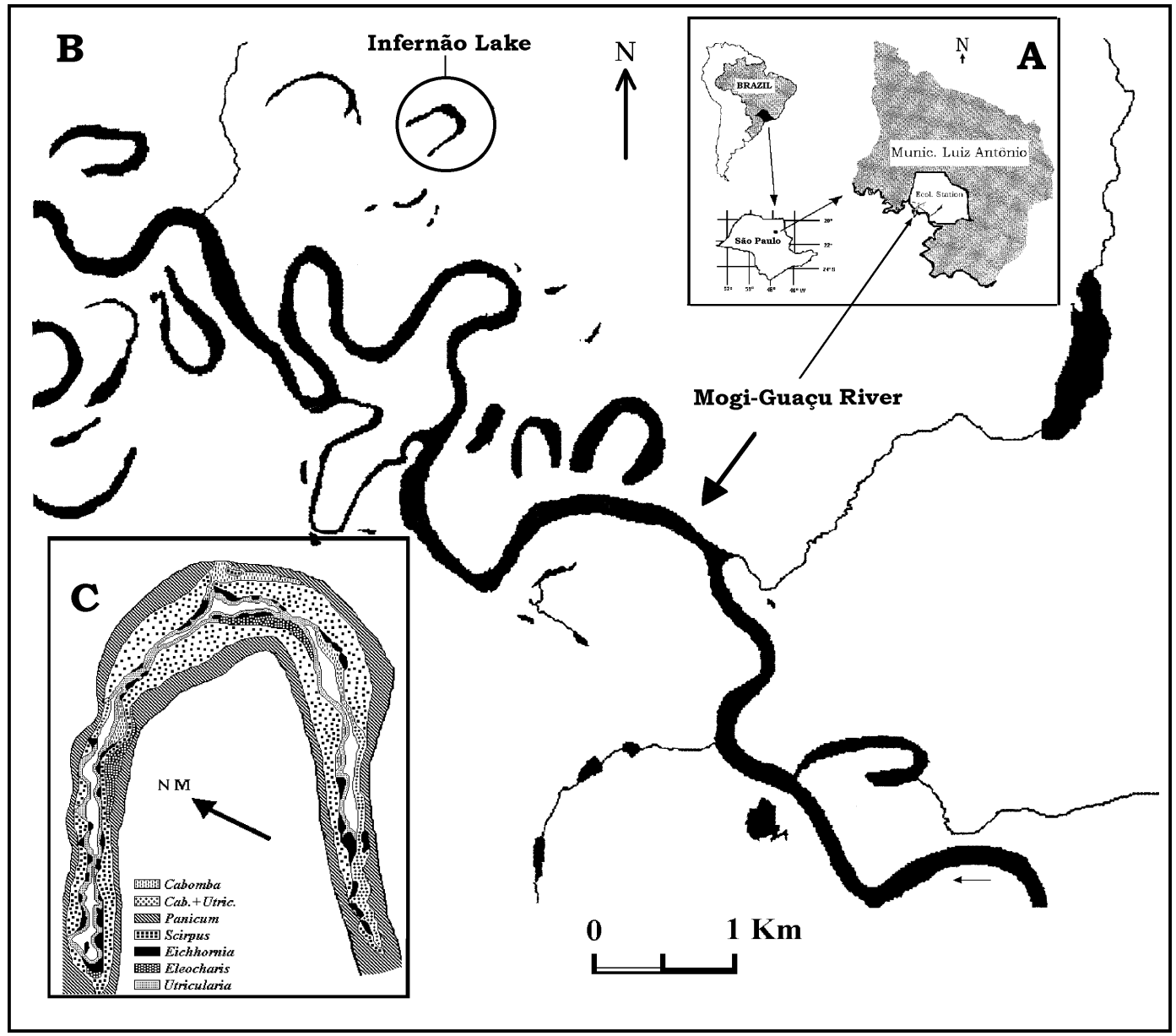

Fig. 1 - (a) Jataí Ecological Station localization in São Paulo State-BR. (b) Mogi-Guaçu River section in Jataí Ecological Station. (c) Main macrophytes distribution in Infernão Lake (modified from Correia \& Trivinho-Strixino, in press). 


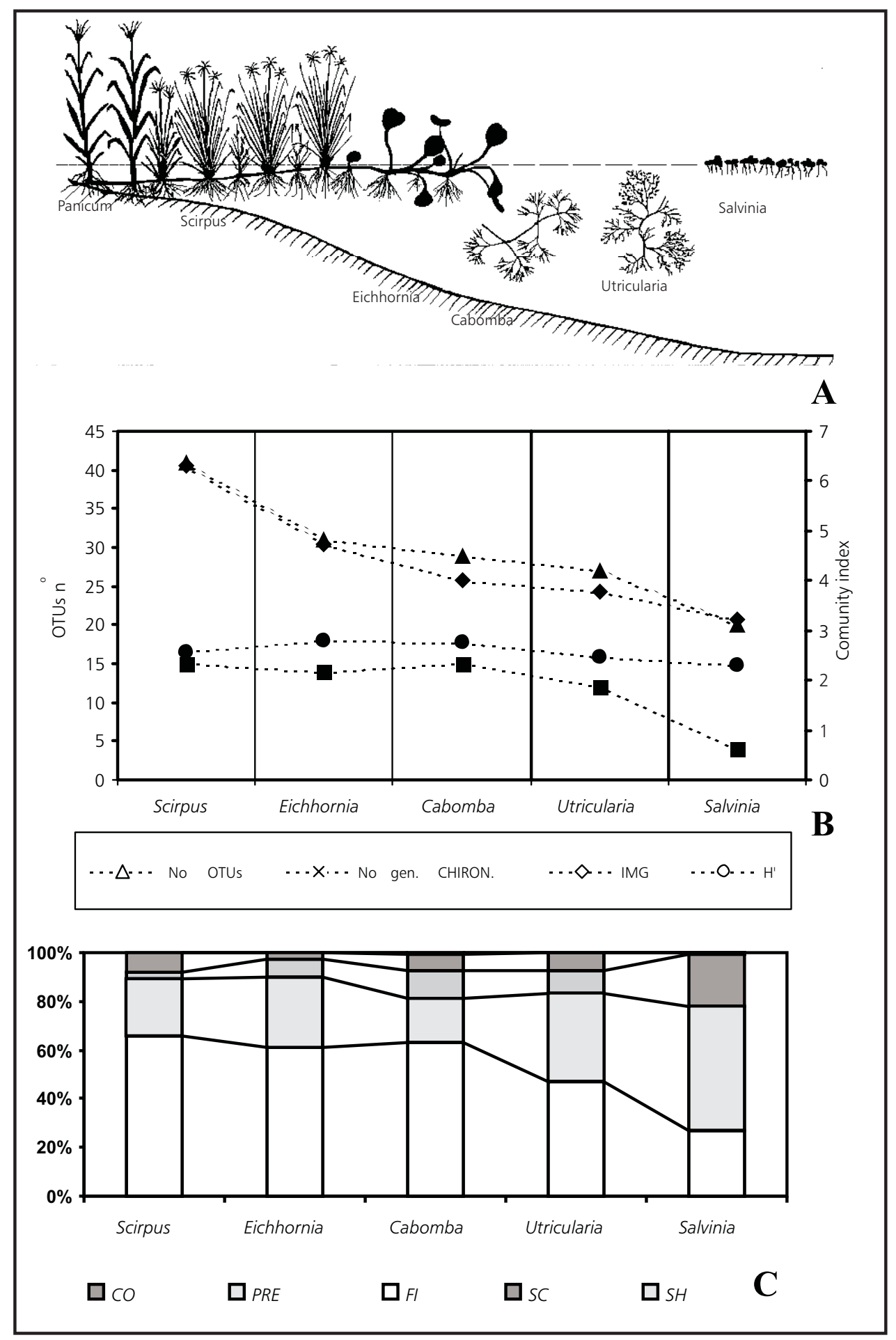

Fig. 2 - (a) Schematic profile of the main macrophytes of Infernão Lake. (b) Operational taxonomic units (OUTs), genera numbers, and community indexes of the phytophilous macrofauna in different aquatic macrophytes $\left(\mathrm{I}_{\mathrm{Mg}}-\mathrm{Margalef} \mathrm{s}\right.$ index, H' - Shannon's diversity index). (c) Relative feeding guilds distribution of the phytophilous macrofauna on different macrophytes. (PRE - predators, FI - filterers, $\mathrm{CO}$ - collectors, SC - scrapers, $\mathrm{SH}$ - shredders). 
TABLE 1

Mean numeric densities (n. $0.01 \mathrm{~m}^{-3}$ ) of aquatic macrophyte macroinvertebrate families in Infernão Lake.

\begin{tabular}{|c|c|c|c|c|c|}
\hline Taxa & Scirpus & Eichhornia & Cabomba & Utricularia & Salvinia \\
\hline Libellulidae & 25.1 & 6.3 & 16.6 & 88.6 & 25.0 \\
\hline Coenagrionidae & 0.4 & 2.5 & 5.0 & 2.5 & 46.6 \\
\hline Gomphidae & & 12.7 & & & \\
\hline Aeshnidae & 0.4 & 1.2 & & & \\
\hline Baetidae & 0.4 & 3.8 & & & \\
\hline Caenidae & 10.8 & 10.2 & 15.0 & 10.1 & 5.0 \\
\hline Ephemerellidae & 0.4 & & & & \\
\hline Hydroptilidae & & & 1.62 & & 0.8 \\
\hline Nepidae & & & & 2.5 & \\
\hline Pleidae & 4.5 & 6.3 & 6.6 & 65.8 & 5.8 \\
\hline Corixidae & 0.4 & 5.1 & 8.3 & & \\
\hline Notonectidae & 4.5 & & & & \\
\hline Belostomatidae & & & & 2.5 & \\
\hline Hydrophilidae & 0.4 & 1.2 & & & 7.5 \\
\hline Curculionidae & 0.4 & & & & \\
\hline Dytiscidae & 0.7 & & & 2.5 & \\
\hline Noteridae & 7.5 & & 8.3 & & 3.3 \\
\hline Helodidae & & 1.2 & & & 3.3 \\
\hline Pyralidae & & & 5.0 & & \\
\hline Dixidae & & & & 5.1 & \\
\hline Tabanidae & 2.3 & & & & \\
\hline Culicidae & 0.4 & 11.4 & 3.3 & 2.5 & 69.2 \\
\hline Ceratopogonidae & 21.0 & 44.4 & 38.4 & 45.6 & 35.0 \\
\hline Chironomidae & 244.4 & 276.3 & 634.9 & 235.5 & 139.2 \\
\hline Naididae & 231.2 & 144.6 & 336.8 & 258.4 & 12.4 \\
\hline Tubificidae & 2.3 & & & & \\
\hline Glossiphoniidae & 5.3 & 26.7 & & 5.1 & \\
\hline Planorbiidae & 2.6 & 16.5 & & 20.2 & 1.7 \\
\hline n. . $0.01 \mathrm{~m}^{-3}$ & 565.4 & 570.4 & 1079.8 & 746.9 & 354.8 \\
\hline Families n. & 21 & 16 & 12 & 14 & 13 \\
\hline
\end{tabular}

The faunistic gradient of the phytofauna in the lake vegetation is shown in Fig. 2b; it clearly indicates, in the direction margin-center of the lake of, a reduction, not only in the number of taxonomic units, as well as in the community indexes values.

\section{Chironomidae and Naididae}

The macrophytes presented associations and numerical densities differentiated (Table 2):
- S. cubensis, with mean numeric density of 244.4 larvae. $0.01 \mathrm{~m}^{-3}$, was represented by 15 genera, of the which Chironomus (121.4 larvae. $0.01 \mathrm{~m}^{-3}$ ) and Beardius (25.5 larvae $0.01 \mathrm{~m}^{-3}$ ) were dominant (> 10\%);

- E. azurea with mean numeric density lightly higher (276.3 larvae . $0.01 \mathrm{~m}^{-3}$ ) distributed in 14 genera, had Goeldichironomus (105.3 larvae . $0.01 \mathrm{~m}^{-3}$ ) and Asheum (66.0 larvae . $0.01 \mathrm{~m}^{-3}$ ) as the most representative taxa; 
TABLE 2

Mean numeric densities $\left(\mathrm{n}^{0} .0 .01 \mathrm{~m}^{-3}\right)$ of aquatic macrophyte Chironomidae genera in Infernão Lake.

\begin{tabular}{|c|c|c|c|c|c|}
\hline Genera & Scirpus & Eichhornia & Cabomba & Utricularia & Salvinia \\
\hline Ablabesmyia & 6.0 & 16.5 & 71.6 & 10.1 & \\
\hline Labrundinia & 8.6 & 15.2 & 31.6 & 15.2 & 34.2 \\
\hline Larsia & 0.4 & 1.2 & & 7.6 & \\
\hline Monopelopia & 0.7 & 7.6 & 13.3 & 5.1 & 22.5 \\
\hline Pentaneura & 0.4 & & & & \\
\hline Fittkauimyia & 0.4 & 1.2 & & & \\
\hline Nimbocera & 0.4 & & 6.7 & & \\
\hline Tanytarsus & 3.4 & 1.2 & 58.3 & 35.4 & \\
\hline Tanyt. Gênero A & 2.6 & 29.2 & 50.0 & 30.4 & 5.8 \\
\hline Tanyt. Gênero $C$ & & & 3.3 & & \\
\hline Asheum & 15.0 & 66.0 & 118.4 & 17.7 & \\
\hline Beardius & 25.5 & 8.8 & 74.9 & 55.7 & \\
\hline Chironomus & 121.4 & & 40.1 & 40.6 & \\
\hline Dicrotendipes & & 6.3 & & & \\
\hline Goeldichironomus & 14.6 & 105.3 & 6.7 & & \\
\hline Nilothauma & & & 3.3 & & \\
\hline Parachironomus & 24.4 & 10.2 & 126.7 & 7.6 & \\
\hline Polypedilum & 20.6 & 3.8 & & 2.5 & 74.2 \\
\hline Tribelos & & & 8.3 & & \\
\hline Cricotopus & & 3.8 & 21.7 & 7.6 & \\
\hline Corynoneura & & & & & 2.5 \\
\hline n. . $0.01 \mathrm{~m}^{-3}$ & 244.4 & 276.3 & 634.9 & 235.5 & 139.2 \\
\hline Genera n. & 15 & 14 & 15 & 12 & 5 \\
\hline
\end{tabular}

- C. piauhyensis was the vegetable that sheltered the largest number of Chironomidae (634.9 larvae . $0.01 \mathrm{~m}^{-3}$ ) distributed in 15 genera, with dominance of Parachironomus (126.7 larvae . $\left.0.01 \mathrm{~m}^{-3}\right)$, Asheum (118.4 larvae . $0.01 \mathrm{~m}^{-3}$ ) and Beardius (74.9 larvae . $0.01 \mathrm{~m}^{-3}$ );

- Utricularia sp., in spite of the morphological likeness with Cabomba, presented smaller numeric density (235.5 larvae . $0.01 \mathrm{~m}^{-3}$ ), with Beardius (55.7 larvae . $0.01 \mathrm{~m}^{-3}$ ) and Chironomus (40.6 larvae . $0.01 \mathrm{~m}^{-3}$ ) being predominant;

- S. auriculata was the vegetable with the smallest numeric density and smaller taxa number; Polypedilum (74.2 larvae . 0.01 $\left.\mathrm{m}^{-3}\right)$, Labrundinia $\left(34.2\right.$ larvae $\left.0.01 \mathrm{~m}^{-3}\right)$ and Monopelopia (22.5 larvae . $0.01 \mathrm{~m}^{-3}$ ) were the dominant genera in this vegetable.

Although the tribe Chironomini has been predominant in all the macrophytes, it is observed a discreet increase of Tanytarsini participation in C. piauyhensis and Utricularia sp. and of Pentaneurini (Tanypodinae) in S. auriculata (Fig. 3).

The family Naididae was represented by 8 species, which Dero (Dero) nivea was the most abundant in most of the macrophytes (Table 3); Dero (Aulophorus) lodeni was dominant in $\mathrm{S}$. cubensis and E. azurea. S. auriculata was the vegetable that presented the smallest number of these worms. 
TABLE 3

Mean numeric densities $\left(\mathrm{n}^{0} \cdot 0.01 \mathrm{~m}^{-3}\right)$ of aquatic macrophyte Naididae species in Infernão Lake.

\begin{tabular}{|c|c|c|c|c|c|}
\hline Species & Scirpus & Eichhornia & Cabomba & Utricularia & Salvinia \\
\hline A. paraguaiensis & 11.2 & & 13.3 & 15.2 & 4.1 \\
\hline Dero (D.) nivea & 83.6 & 54.6 & 256.7 & 238.0 & 6.7 \\
\hline Dero (D.) evelinae & 11.6 & 31.7 & 18.5 & & 0.8 \\
\hline Dero (A) borelli & 0.4 & & & & \\
\hline Dero (A) carteri & 0.4 & & & 5.2 & \\
\hline Dero (A) lodeni & 121.4 & 58.3 & & & 0.8 \\
\hline Nais comunis & & & 48.3 & & \\
\hline Slavina evelinae & 2.6 & & & & \\
\hline n. . $0.01 \mathrm{~m}^{-3}$ & 231.2 & 144.6 & 336.8 & 258.4 & 12.4 \\
\hline Species n. & 7 & 3 & 4 & 3 & 4 \\
\hline
\end{tabular}

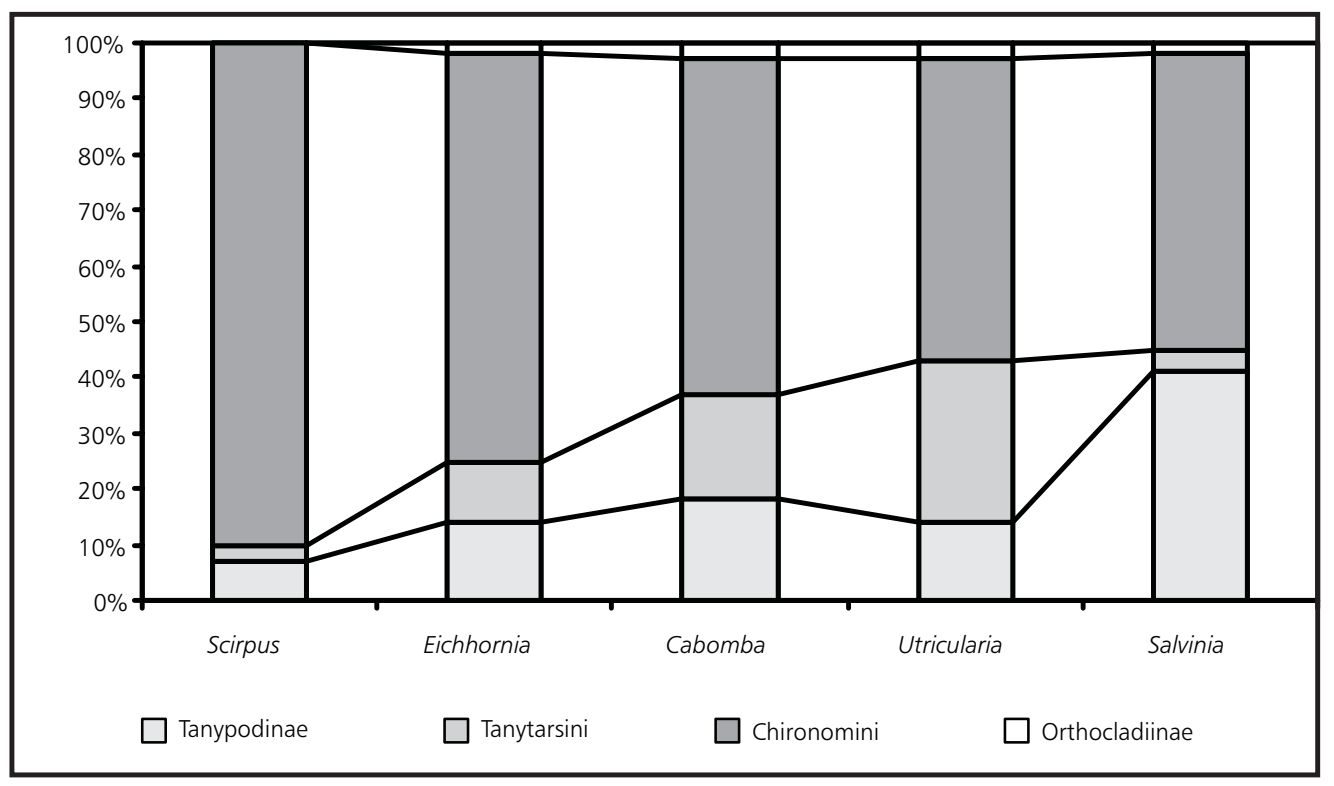

Fig. 3 - Relative distribution of Chironomidae subfamilies and tribes in different macrophytes of Infernão Lake.

\section{Coenotic likeness}

Through the analysis of the diverse taxonomic categories, and of the Chironomidae and Naididae taxa, it was obtained a reduced taxocoenotic similarity among the aquatic macrophytes (PSc < 50\%) (Fig. 4a), which suggests peculiar characteristic of each biotope. Despite of this low similarity, the dendrogram gathered the most alike macrophytes, according to foundation manners (S. cubensis $\mathrm{x}$
E. azurea-emergent and rooted; $C$. piauhyensis x Utricularia sp. - submerged; S. auriculata fluctuant).

Unlike the taxocoenotic differences, the feeding guilds analysis indicated high similarity among the community's functional categories in most of the macrophytes (PSc > 60\%) (Fig. 4b). As shown in Fig. 2c, the phytophilic community was composed, in its majority, by collector forms. 


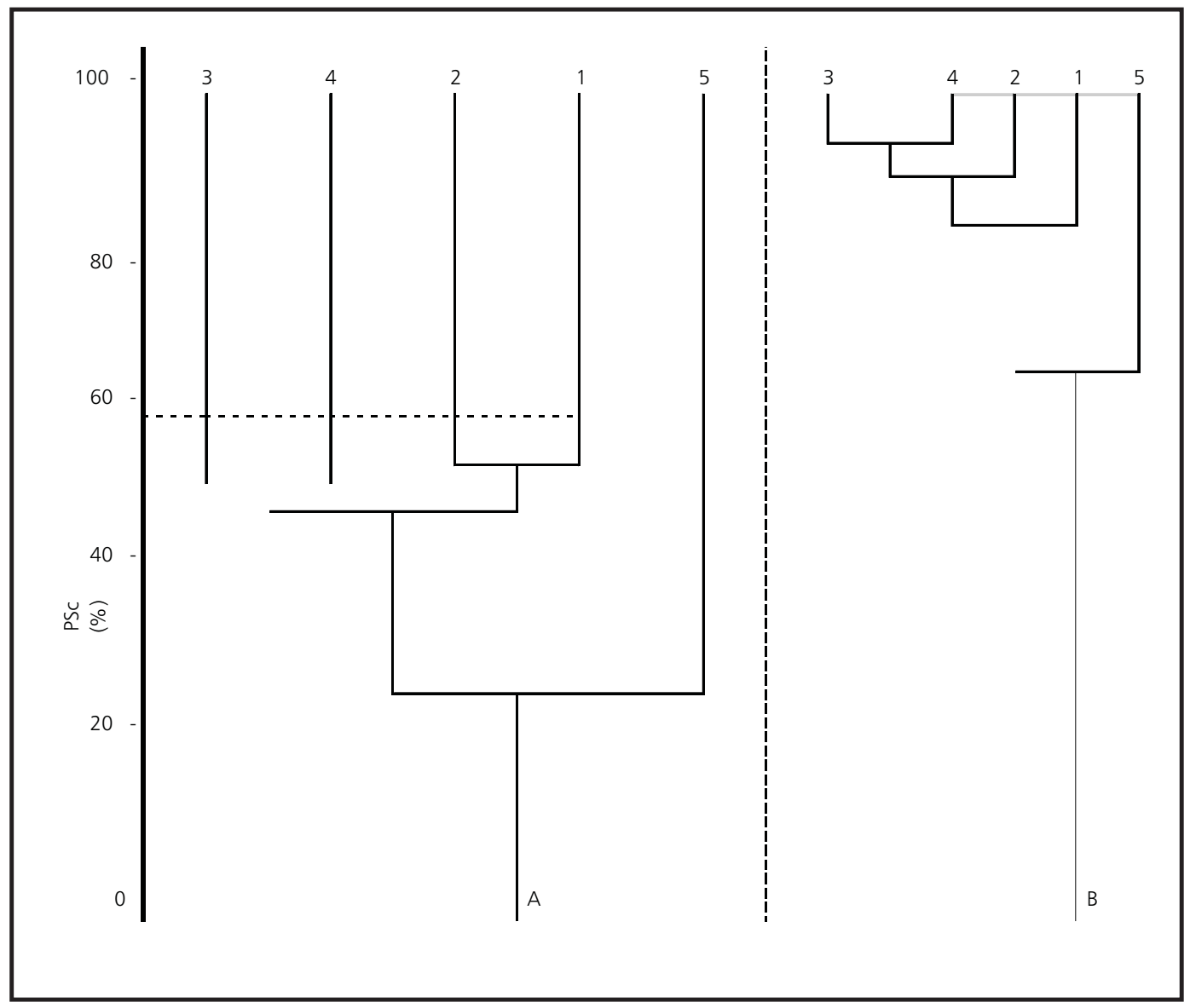

Fig. 4 - Aquatic macrophyte similarity dendrogram (PSc) in Infernão Lake. (a) Established on taxonomic differences of associated fitofauna. (b) Established on associated fitofauna feeding guilds. (1 - Scirpus cubensis, 2 - Eichhornia azurea, 3 - Cabomba piauhyensis, 4 - Utricularia sp., 5 - Salvinia auriculata).

This fact is due to the high participation of Naididae and Chironominae that are predominantly detritivores. Among the predators groups, Libellulidae, Coenagrionidae, Ceratopogonidae and Tanypodinae, were the taxa with more contribution, although the larvae of this last one are not obligated predators, frequently presenting in its diet, other food categories, as great algae (Desmidiaceae and Bacillariophyceae), a fact already pointed out by different authors (Roback, 1969; Trivinho-Strixino $\&$ Strixino, 1993). Furthermore, a collectors decrease tendency was found, and predators and filterers increase tendency as well, in the direction margincenter of the lake. This is explained by the morphologic characteristics and of establishment of the macrophytes. S. cubensis and E. azurea, with long and tangle roots, forming a "rug" that favors the detritus accumulation and, therefore the presence of collectors; opposed S. auriculata being a flotation macrophyte with small roots, it gives little surface of detritus retention. This sheltered groups, which possibly use the vegetable as a support, or refuge, as it is the case of the nymphs of Odonata and of the larvae of Ceratopogonidae and Tanypodinae. It also explains, the high filtrators participation, in particular of Culicidae larvae, which use this vegetable only as a support, and filter materials in suspension in the open water. The small contribution of the shredders is in agreement with other studies (Glowacka et al., 1976; Lamberti \& Moore, 1984; Strixino \& Trivinho-Strixino, 1984; TrivinhoStrixino \& Strixino, 1993). 
The macroinvertebrate collectors dominance indicates the prevalence of a detritivore chain in the macrophytes, and, as pointed out by Mastrantuono (1986), this could be constituted in an indication of trophic enrichment of the lake, fact this already detected in Infernão lake by the invasion of $S$. cubensis that in the last years has been occupied great part of the lake. In addition, the phenological characteristic of $S$. cubensis, with only renewing of the emergent parts, results in the increasing accumulation of organic deposits in its rizosphere (Carlos, 1991). It is assumed that this invasion will result in the decrease or disappearance of the others macrophytes, and consequently, will change the whole macroinvertebrate community structure. Probably this community will be characterized by the predominance of tolerant detritivore forms.

The accelerated senescence and eutrophication in this lake seems to have been able to originate an analogous situation investigated by Dvorák (1996), in the shallow eutrophic Lake Loosdrecht, where the process results in selecting and supporting detritivore and filtering forms.

Thus, although a taxocoenotic differentiation is exhibited, according to macrophyte pattern, the operational likeness is maintained.

\section{REFERENCES}

ANTÔNIO, R. M., 1996, Estimativa da capacidade heterotrófica da Lagoa do Infernão (Estação Ecológica de Jataí - Luiz Antônio, SP). Dissertação de Mestrado. São Carlos, UFSCar, 79p.

CARLOS, V. M., 1991, Aspectos ecológicos da associação vegetal de Scirpus cubensis na Lagoa do Infernão, SP. Dissertação de Mestrado, São Carlos, UFSCar, 87p.

CORREIA, L. C. S. \& TRIVINHO-STRIXINO, S., 1998, Macroinvertebrados da rizosfera de Scirpus cubensis na Lagoa do Infernão (Estação Ecológica de Jataí, SP): estrutura e função. Acta Limnologica Brasiliensia, 10 (in press).

COUTINHO, M. E., 1990, Ecologia populacional de Eichhornia azurea e sua participação na dinâmica da vegetação aquática da Lagoa do Infernão, SP. Dissertação de Mestrado, UFSCar, São Carlos, 145p.

DVORÁK, J., 1996, An example of relationships between macrophytes, macroinvertebrates and their food resources in a shallow eutrophic lake. Hydrobiologia, 339: 27-36.
ESTEVES, F. A., 1988, Fundamentos de Limnologia. Rio de Janeiro, Interciência/FINEP, 575p.

GANDOLFI, N., 1968, Bacia do Rio Mogi-Guaçu: morfometria da drenagem, sedimentologia e investigações físico-químicas. Ph. D. thesis, EESC-USP, São Carlos, SP, 124p.

GLOWACKA, I., SOSZKA, G. J. \& SOSZKA, H., 1976, Invertebrates associated with macrophytes. In: E. Pieczynska (ed.), Selected problems of lake littoral ecology. Wydawnictwa Uniwersytetu Warszawskiego, Warszawskiego, Warszawa, 238p.

LAMBERTI, G. A. \& MOORE, J. W., 1984, Aquatic insects as primary consumers. In: V. H. Resh \& D. M. Rosenberg (eds.), The ecology of aquatic insects. Praeger Publishers, N.Y., 625p.

MASTRANTUONO, L., 1986, Community structure of zoobenthos associated with submerged macrophytes in the eutrophic Lake Nemi (Central Italy). Boll. Zool., 53: 41-47.

MERRITT, R. W. \& CUMMINS, K. W. (eds.), 1995, An introduction to the aquatic Insects of North America. Dubuque: Kendall/Hunt Publ. Co., 861p.

NOGUEIRA, F. M. B., 1989, Importância das macrófitas aquáticas E. azurea e S. cubensis na ciclagem de nutrientes e nas principais características limnológicas da Lagoa do Infernão, SP. Dissertação de Mestrado, UFSCar, São Carlos, 130p.

ROBACK, S. S., 1969, Notes on the food of Tanypodinae larvae. Ent. News, 80: 13-18.

STRIXINO, G. \& TRIVINHO-STRIXINO, S., 1984, Macroinvertebrados associados a tapetes flutuantes de Eichhornia crassipes (Mart.) Solms, de um reservatório. An. Sem. Reg. Ecol., IV: 375-397.

STRIXINO, G., TRIVINHO-STRIXINO, S. \& ALVES, G. R., 1997, Macroinvertebrados bentônicos de lagoas marginais da planície de inundação do Rio Mogi-Guaçu (Estação Ecológica de Jataí). An. VIII Sem. Reg. Ecol. V., I: 33-42.

TRIVINHO-STRIXINO, S. \& STRIXINO, G., 1993, Estrutura da comunidade de insetos aquáticos associados à Pontederia lanceolata Nuttal. Rev. Brasil. Biol., 53(1): 103-111.

TRIVINHO-STRIXINO, S., GESSNER, F. A. \& CORREIA, L., 1998, Macroinvertebrados associados a macrófitas aquáticas das lagoas marginais da Estação Ecológica de Jataí (Luiz Antônio, SP). An. VIII Sem. Reg. Ecol., V.III: 1189-1198.

WHITTAKER, R. H. \& FAIRBANKS, C. H., 1958, A study of plankton and copepod communities in the Columbia Basin, south-eastern Washington. Ecology, 39: 46-65. 